\title{
INTERNET MARKETING AS A TOOL FOR THE DEVELOPMENT OF INDUSTRIAL ENTERPRISES IN MODERN ECONOMIC CONDITIONS
}

Formulation of the problem. With the development of the economy of Ukraine in the market is increasing competition. For industrial enterprises, the issue of survival most urgently arises, forcing them to fight for the consumer, to seek new, more effective forms of communication to promote products. The constant changes lead to the development of marketing and the emergence of new tools of interaction with consumers and other market participants.

The result of such a transformation can be considered Internet marketing. In today's society, Internet marketing plays an important role in the activities, development and organization of an industrial enterprise. Research shows that e-commerce is growing rapidly, because the right and timely use of Internet technologies ensures revenue growth and cost savings through traditional marketing tools. That is why it is advisable to talk about the development of a new direction of research, which is an important component of integrated marketing enterprise - Internet marketing (or e-marketing, online marketing). It allows you to view the traditional 4P marketing mix (Product, Price, Price, Place, Promotion) through the prism of online features [1].

However, most Ukrainian businesses do not use all the promotion options and do not have all the necessary elements to get the most effective results and minimize the costs of implementing an online marketing system.

Analysis of recent research. Many researches of scientists are devoted to the solution of problems of Internet marketing, Sokrem, L. Vinarika, O. Shchedrina, N. Vasilion [3], M. Makarova [4], D. Straus [5], R. Uilsona [6], I. Uspensky [7], V. Kholgomogorov [8].

Most authors, working in the given sphere don't violate Internet marketing in self-identity science field. So, I. Uspensky notes, Interthere are no unary characteristics, but I am aware of the characteristics of traditional tools tiv marketing. One of them - hypermedia nature. Accordingly, he feeds there Internet-marketing as a new straightforward marketing - gipermarketing as theory and methodology of organization marketing in hypermedia middleware Internet [7].

M. Makarova considers Internet marketing warehouse part of the foreign marketing country tags and firms and defines it as technology marketing with the help of computer systems that measure. In the Internet fully nominate only those tasks Firms, so be effective from the point of view of income that costs [4].

The modern realities of functioning of Ukrainian enterprises require the use of appropriate tools for the formation and development of competitive advantages, some of which are components of the marketing complex.

Their research is devoted to the works of leading domestic and foreign scientists, such as I. Boychuk, A. Zagorodniy, T. Auckland, V. Holmogorov and many others. The main factors for improving the efficiency of business activity of enterprises are based on the intensive use of marketing communications, the functions of which are to convey to consumers information about the unique properties of products (goods, services, ideas), stimulate demand, maintain customer loyalty, forming a positive image of enterprises. These issues are addressed in the works of O. Klichuk, M. Auckland, B. Halligan. O. Yashkina.

The purpose of the article is to substantiate the use of Internet marketing as a tool for the development of thought-provoking enterprises in order to ensure the efficiency of commercial activity of enterprises in modern conditions of management.

Outline of the main research material. With the formation and development of the information economy, Internet technologies have given industrial enterprises a new tool for doing business and doing business in general. Usually, their use is aimed at reducing costs, increasing sales and expanding marketing communications with consumers.

Internet technologies have proven to be highly effective in the enterprise marketing policy-making system. Consumers themselves received a new information source on products and services, new ways to meet their needs through the opportunity to interact with a wider range of businesses [2]. Recent studies show that the use of Internet technologies in marketing brings real profits and significant savings in resources.

In the context of global computerization, the role of internet marketing will grow, driven by convenience and benefit for both the consumer and the business. Today, the Internet is one of the most effective marketing channels. The advantages of Internet marketing in the activities of industrial enterprises are: 
1) a high degree of personalization (if traditional marketing is aimed at the mass consumer, then everyone's opinion is taken into account on the Internet);

2) interactivity (clients are involved in the business processes of the enterprise by participating in surveys, forming the reputation of the company, attracting new customers);

3) a large amount of information which is impossible to receive offline (on the Internet you can highly estimate the effectiveness of advertising, determine the number of visitors, their interests, get feedback, successfully conduct competitive intelligence.

An important component of industrial enterprise internet marketing is the creation and development of your own website.

It can significantly improve economic performance, for example, increase sales, refine search for your target audience, that is, relevant leads. Creating your own website, from the point of view of Internet marketing, can proceed in the following stages: 1) defining the functions and tasks of the site; 2) research of the target audience; 3 ) development of site structure;
4) choice of site design and style (graphic representation of the site, which should be effective and effective); 5) selection of a navigation model that would provide ease of access to the information component of the site; 6) provision of information support and support; 7) hosting definition (choosing where the site will physically be hosted).

After defining the goals and objectives of the site, structure and design, selecting a target audience and advertising is extremely important. As for the target audience, its number on the Internet increases every day. The development of the domestic Internet space is ambiguous, but analysts estimate that the number of Internet users in Ukraine will increase rapidly in the coming years. This is facilitated by the following factors: Increase in the sale of Internet access media; increase of opportunities of Internet providers; increase of speed of the Internet, stabilization of traffic. Fig. 1 shows the components and tools of Internet marketing for Ukrainian industrial enterprises. The use of online marketing tools greatly expands the capabilities and characteristics of the traditional marketing environment.

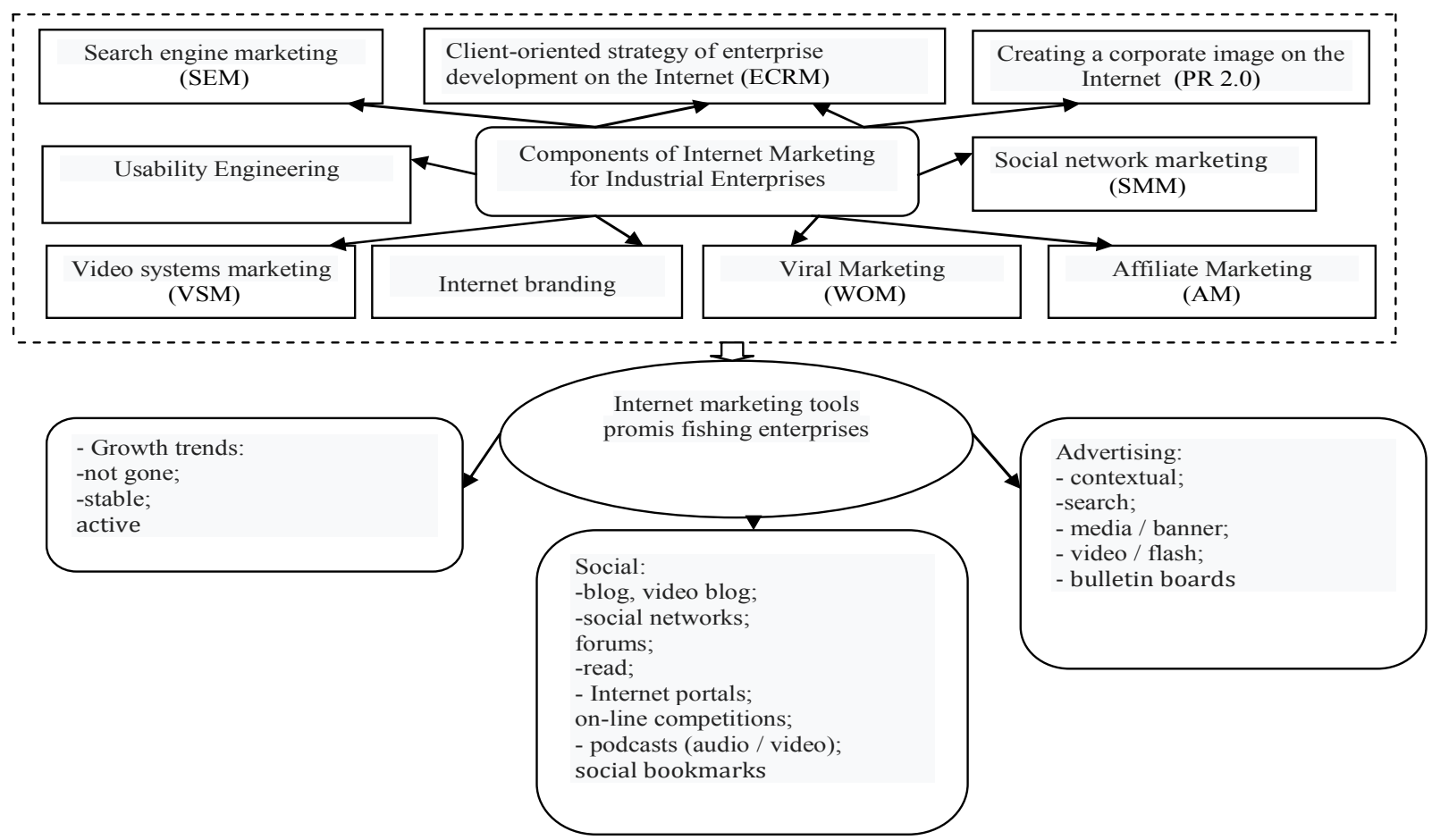

Fig. 1. Ingredients and tools of internet marketing of Ukrainian industrial enterprises (developed by source [9])

For example, the Internet provides high efficiency in the presentation and assimilation of information, which strengthens the relationship between the manufacturer, seller (enterprise) and consumers. It is effectively used for field and office marketing research, thereby providing an analytical marketing function. In addition, the Internet can reduce the costs of marketing campaigns, as opposed to traditional media. Now any industrial enterprise active in the World Wide Web can easily change market boundaries (move from local to international markets) and introduce new tools and opportunities for competition. The possibility of introduction of Internet technologies depends on the peculiarities of functioning of enterprises, industry and scale of activity, degree of dependence on network space.

The modern strategy of marketing of industrial enterprises is aimed at attracting and retaining customers, finding opportunities to increase sales of goods and ser- 
vices. Businesses operating in a globalized world are more than ever interested in turning potential clients into real ones. That is why social networks are considered as one of the main factors influencing business. The modern method of communication on the Internet - honest conversations and communication with the audience through relevant content.

It is nowadays important to include content marketing in public relations and to prepare quality content for placement on the site and on social networks.

Globalization is an additional incentive for industrial enterprises to engage content marketing in marketing communications: real and potential consumers are accelerating the pace of migration, changing methods of competition for the consumer, and therefore the enterprise should expand the boundaries of information dissemination. Content marketing is a promising means of marketing communication due to the rapid development of modern technologies that allow you to create all kinds of online publications (websites, digital magazines, e-mailings). In this period, industrial enterprises continue to actively apply the methods of SEO, SEM, SMM, as well as other methods (display advertising, viral marketing), but at a new level due to the technical development of the Internet. Virtual communications are more effective: you can maximize (target) communications to your target audience (geographically, by time, context, user behavior, product type or service, etc.), monitor and quickly monitor their performance with Google AdWords, line adjust. One of the components of the process of conquering the market is marketing communications.

Today much of the variety of advertising is becoming less effective. Standard advertising does not elicit a conscious reaction from buyers. The company is forced to sell its products, accompanying them with original, informative and attractive appeals that would convince the conformity of these goods to the needs and desires of consumers. The application of marketing innovations in the marketing communications system is an extremely pressing issue because of the oversaturation of the market with traditional advertising. But, because innovation is a fleeting thing, analysis of the latest technology in marketing communications should be done using online resources where information on marketing innovations in the marketing communications market appears in the form of blogs, analytical reports and popular articles. It should also be noted that not all innovative technologies or the latest trends in the marketing communications market can be extrapolated and implemented into commercial and industrial activities of industrial enterprises.

And it can be caused both by subjective (absence of innovative marketing vision in the management of the enterprise, insufficient level of qualification of marketing service of the enterprise), and objective reasons (inconsistency of innovations of the direction of business activity, orientation of innovation not at the target audience of industrial enterprise, lack of funds of industrial enterprise, lack of etc).

Today, Internet marketing highlights many tools that are effective for an industrial enterprise. Let's look at some of them.

Contextual advertising is a fairly new and easyto-use tool that has many support services and applications, even freeware. These apps help you select the most popular and potentially most profitable keywords, automatically calculate your monthly budget, generate statistical reports related to internet marketing, such as: clicks per day, number of searches for your keywords, clicks on each keyword, and more. functions.

These add-ons greatly automate the process of advertising campaigns at each stage. According to observations in Ukraine on the effectiveness of Internet advertising is occupied by Google. Yandex Direct takes second place, and all other systems are far behind in terms of implementation and usage efficiency. Banner advertising also plays a special role. Using this tool requires more professionalism from a specialist who is a promoter.

The main tasks at this stage are: to analyze the target audience, to choose the right advertising pitches, the form of the advertisement submission and to perform all actions in order to understand and feel the client's purpose. The client's goal is not always taken into account, and in the future, this leads to insufficient attention in the choice of the target audience. Search engine promotion or SEO is an online marketing that is characterized by text content and product advertising on social networks. A large share of the market is owned by outsourced online agencies, purchasing services from freelancers or specialist companies. This approach often leads to unprofessional consulting of the client, an increase in the real cost of the service, as well as the absence of any guarantees. In order to properly evaluate the effectiveness of the use of Internet marketing tools, it is important to clearly identify all the components of marketing costs, bring statistics to the target audience, identify the main basics of consumer impact and position among all competitors in the internal market.

Savings on marketing costs when implementing individual measures of Internet marketing is manifested in:

- saving on advertising costs (by maintaining an online store, producing video clips, running a forum, blog, etc.);

- savings on telephone calls;

- saving time to study products (all can be seen on the company's website);

- savings on speed before and after sales service;

- much lower costs for opening and operating an online store.

According to the survey, one third of Ukrainian companies consider selling goods via social networks 
and only $20 \%$ consider establishing communication with consumers not on social networks. That is, the domestic market is rapidly introducing Internet marketing into the activities of the industrial enterprise, as well as realizing the potential of social networks in marketing communication activities on the Internet [10].

Any kind of activity the enterprise tries to apply influence on consciousness of "the" consumer. Among the tools that affect group consciousness are the following: verbal and non-verbal information. By using various methods, tools and mechanisms of social psychology, it is possible to influence the basic principles of group consciousness, which are formed as a result of interaction of community members on the Internet and create the desired context for further communication. The organizational stage of the mechanism of realization of the concept of crowd-marketing, in accordance with the two-circuit model of communication, involves work in two directions: organization of work regarding the formation of the context of the information level of communication influence and the organization of traditional marketing communication with consumers. The main object of influence in the implementation of the concept of crowdsourcing are: network communities, but they are formed not only on social networks, but also on other services of the Internet, where users interact.

An example of forming a network context is a variety of product review sites, aggregator sites, or major online stores, where users post product reviews, rate product ratings, and solicit customers who have already purchased a product. In this way, users on such sites also create a network context, form a majority of the product or manufacturer.

In this case, Internet marketing gives the consumer the opportunity to get information about the products. Any potential consumer can use the Internet and receive information about the product, and most importantly buy it. If, for example, there is no information at all, he will seek that information from a competitor. This should be foreseen and marketers should take action.

The important point is that, unlike traditional marketing methods, online marketing gives a clear statistical picture of the effectiveness of a marketing company. Compared to other types of media marketing, internet marketing is growing very fast. It is gaining popularity not only in business but also in the general public who want to promote and make money from an effective website or blog. In developed countries, Internet marketing and advertising costs account for about $5 \%$ of total advertising costs [13].

However, Internet marketing has its drawbacks as well. Restrictions in Internet marketing pose problems for both companies and consumers. For example, if a consumer has a slow internet connection, it can make it difficult to use animated commercials, presentation films and high quality graphics in advertising. This issue can be corrected, but it can occur to any consumer. Another inconvenience is that Internet marketing does not allow the consumer to try the product before making a purchase. Most consumers solve this problem simply. They get acquainted with the right product in a regular store, and make a purchase in an online store. There is also the concept of return of goods. Internet marketing should provide that the product may not suit the consumer. The problem of the ability to "touch" the product should also be solved in other ways.

For example, some online store owners use high quality product photos to try to convey all the details and features of their products in the images. Gaining popularity and the use of special photo equipment for digitizing product images in $3 \mathrm{D}$, which allows the visitor to view the product from all angles [10]. Another limiting factor is the limited payment methods trusted by consumers.

Internet applications for payment terminals can fail. Card payment is also not very secure because the consumer is not always sure that the correct details on the site and the goods will arrive on time. Internet marketing in the industrial market is realized with the help of a set of tools. They can be divided into two groups based on the environment in which they are used - internal and external. External tools include those that are visible to consumers and competitors, that is, are responsible for implementing marketing activities online.

These include a company website, a web store, various types of advertising, search engine marketing, social media marketing, email marketing, content marketing, PR and placement on aggregate platforms and platforms. Internal tools serve as a kind of infrastructure for the enterprise. They are responsible for the accumulation, processing and integration of data on the results of marketing activities of the company in the network.

They cover CRM systems and a variety of webbased tools that provide analytics for specific tools (website, search engine optimization, social networks, brand mentions in social media, and more). Thus, as a result of the digital marketing audit of the major industrial enterprises operating in this market in Ukraine, it was found that the level of development of the tools is low.

Not all businesses have their own websites. The most widely used tool is online marketplaces. After all, these platforms are popular with customers and are wellpromoted online. However, trends in the environment of industrial consumers, caused by the development and penetration of Internet technologies, indicate that business, even in traditional industries, needs transformation.

Here are the main ones. According to the statistics portal Statista, during 2013-2017 the volume of e-commerce market in the B2B sector consistently increased on average by $7 \%$ annually (Fig. 2) [11]. 
The specificity of the B2B market usually determines the choice in favor of traditional channels of promotion, which include personal communication with a potential client.

In addition, the feasibility of investing in an Internet channel depends on the particular decision making of the specific target audience. Therefore, executives serving the needs of other businesses and organizations may be conservative when developing a communications strategy, favoring proven tools. Also, the 2017
B2B market exceeds the B2C market by nearly $235 \%$ in volume, according to Statista 2017 Ecommerce Report [12].

This is due to the gradual formation of a culture of doing business online, the development of industrial consumers and Internet providers as a sales channel. The Internet is not just an advertising channel in the media mix of B2B companies, it is part of the business development and marketing strategy of an industrial enterprise.

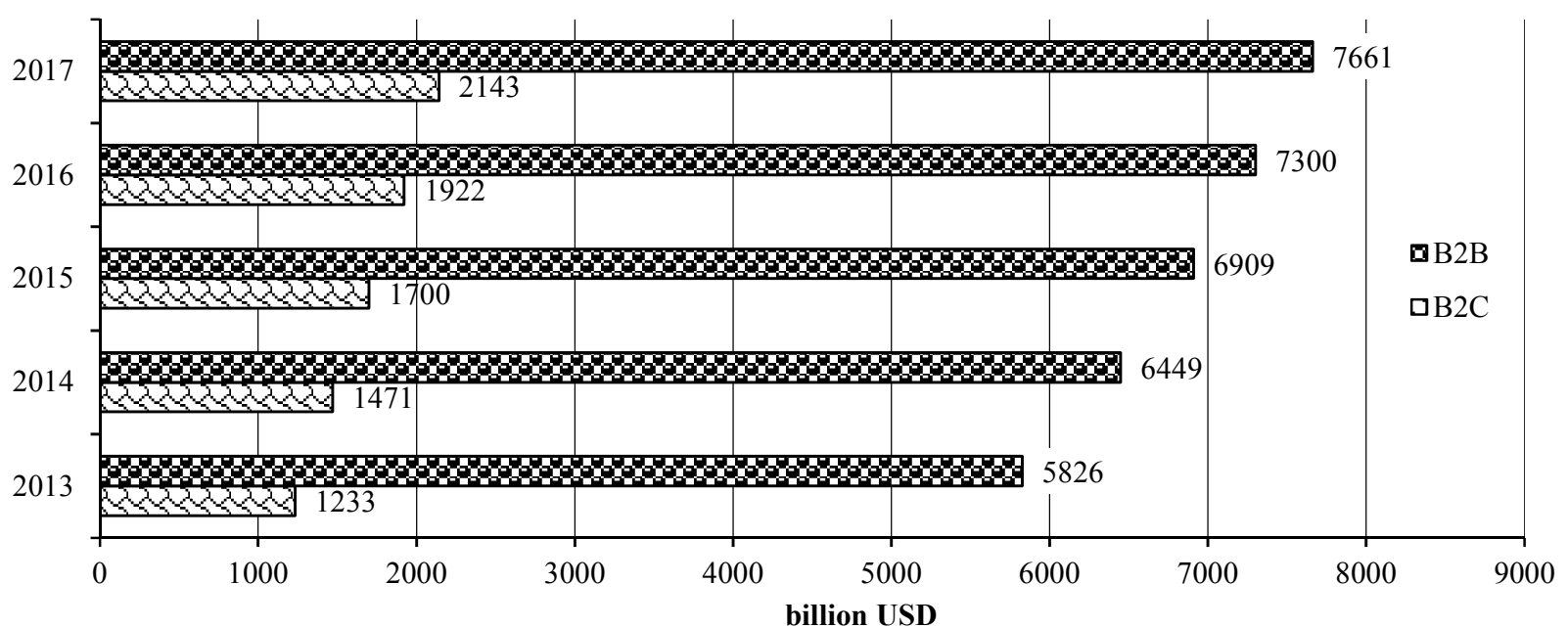

Fig. 2. Global E-Commerce Market Volume 2013-2017, Billion USD United States

(created by authors based on Source [11])

According to Forrester, which researches the development of Internet marketing in the industrial market and provides relevant services, about $90 \%$ of people involved in purchasing industrial products use the Internet to find product information and select a provider. For $74 \%$ of people, half the way to go offline shopping is online.

That is, industrial consumers search, study information on existing offers, evaluate alternatives on the Internet. On average, 6 different online channels are used in the purchasing decision process [15]. According to a survey conducted by the consulting company Accenture in 2014 , only $12.4 \%$ of industrial consumers seek meetings with company representatives or even a telephone conversation (Fig. 3).

Most respondents (71\%) prefer to search and evaluate options online with or without the help of company consultants [16].

For companies operating in the B2B market, this means having to have such an online presence to ensure that each of these groups is complete with information about the company's offerings. According to a study conducted by the Boston Consulting Group with Google in September 2017, which involved more than 2,000 B2B companies, $67 \%$ of purchases were made from information of all kinds available on the Internet.

Before making an online purchase, or at least go to an offline communications channel with a provider of decision-makers, search the web. They search on a variety of queries, browse online catalogs, explore information on websites, compare product specifications, pricing, and more. The search for information at this stage is broader, more fundamental than targeted.

Thus, it is determined that in $71 \%$ of cases the search begins with general queries, ie queries by product category, and not by specific trademarks [17]. This factor must be taken into account when forming a semantic search kernel. According to a 2014/2014 Google / Millward Brown Digital, B2B Path to Purchase Study, a significant change in the demographics of business executives and positions that assume responsibility for procurement was made during 2012-2014.

That is why, when designing an Internet marketing strategy, one should take into account the particular behavior of this category of people, the tools and channels that are popular among them. In addition, the change in management systems in modern companies has led to the fact that the decision to buy is influenced not only by top management, so-called C-suite managers, that is, executives, but also ordinary employees.

Thus, according to the results of the same survey, $81 \%$ of people holding non-managerial positions in the company have the opportunity to influence the decision to buy industrial goods [17]. For B2B companies, this means that you need to build communications that target not only top management, but also influence other employees of the target audience. 


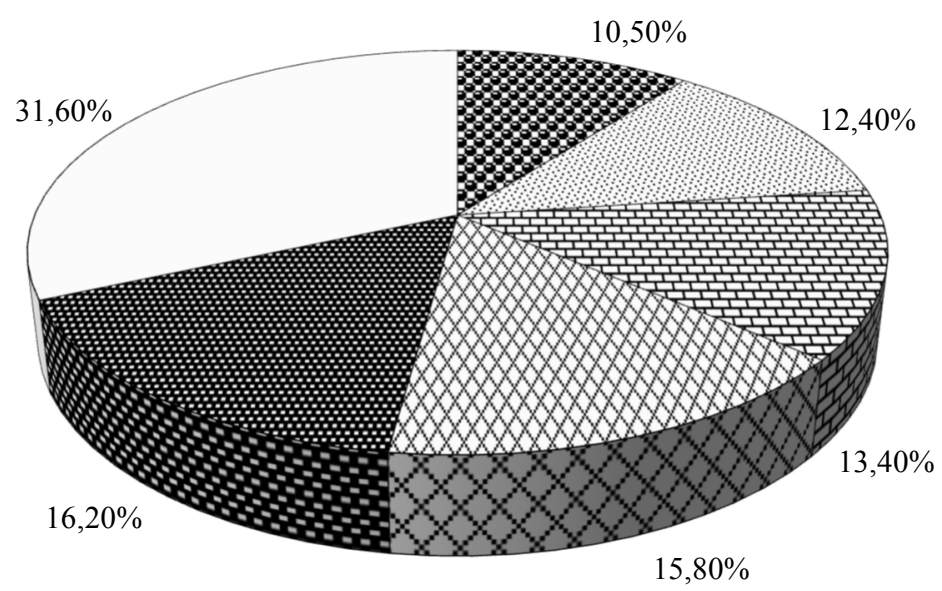

$\mathbf{8}$ I search and buy on my own, no business representative support

요 I prefer personal meetings throughout the decision-making process

II do an online search on my own, but make the purchase by phone

I'm searching and buying online, but I look forward to getting online support for any questions I may have

rommunicate directly with representatives of the telephone company to discuss options throughout the decision-making process

$\square$ I search and buy online, but I look forward to getting online advice and quality service

Fig. 3. Distribution of respondents' answers to the question of involvement of a company consultant in the decision to purchase industrial goods (generated by the author from source [16])

If top management is easy to reach via social networks, because of the complexity of identifying all professionals involved in the purchase of products, more massive, at the same time targeted, tools (blog posts, search engine advertising, whitepapers, etc.) should be used. As for the way to buy in an industrial market that originates on the Internet, it begins in $90 \%$ of cases with relevant search engine queries, according to the Think with Google resource [15].

On average, the consumer in the industrial market performs about 12 searches before proceeding to study information on a particular vendor's website or other specialized resource. This points to the critical importance of search engine marketing for B2B businesses. All these facts are strong arguments in favor of formulating a digital marketing strategy by companies that serve the needs of industrial consumers.

Therefore, we can conclude that the role of the Internet in the decision-making process of purchasing by industrial consumers is increasing. Despite the fact that the results of the research were conducted mainly in more developed countries than Ukraine, the trends are relevant to the Ukrainian market environment. The study found that the consumer is in the crossroads of online and offline communication when making a purchase decision. Accordingly, companies need to consider this fact and formulate a marketing strategy based on the quality integration of the two channels.

Conclusions. Thus, Internet marketing is an important phenomenon in the modern management of industrial enterprises. Improved and updated Internet marketing technologies will help maintain and develop the relationship of the company with customers. This will contribute to the high communication status of the marketing system, increase the effectiveness of marketing activities and expand marketing relationships.
In addition, in today's business environment, it is very difficult to imagine a successful business that has not used at least one type of marketing communications on the Internet: company site, blog, series of videos about the company, etc. The interactive nature of the network environment allows to increase the effectiveness of interaction of all participants of communication, which positively influences the realization of marketing functions of a particular enterprise as a whole.

Features of Internet marketing is that the Internet allows you to dynamically track and adjust the course of a marketing company, and further research should be aimed at developing recommendations for the use of Internet communications by enterprises.

\section{Literature}

1. Комарницький I.Ф. Економічна теорія. Чернівці, 2006. 334. 2. Цифровий маркетинг - модель маркетингу XXI сторіччя: монографія / авт. кол.: М.А. Окландер, Т.О. Окландер, О.І. Яшкіна [та ін.]; за ред. д.е.н., проф. М.А. Окландера. Одеса: Астропринт, 2017. 292 с. 3. Винарик Л.С., Щедрин А.Н., Васильева Н.Ф. Онлайновый электронный рынок: становление, проблемы: монография / НАН Украины, Ин-т экономики пром-сти. Донецк, 2003. 176 с. 4. Макарова М.В. Електронна комерція: посіб. Київ: Академія, 2002. 272 c. 5. Strauss J., Frost R. E-marketing. Upper Saddle River: Prentice-Hall, 2001. 519 p. 6. Уилсон P. Планирование стратегии интернет-маркетинга / [пер. с англ. С.А. Зайцев]. Москва: Издательский дом Гребенникова, 2003. 261 с. 7. Успенский И.В. Интернет-маркетинг: учеб. URL: http://www.aup.ru/books $/ \mathrm{m} 80 /$. 8. Холмогоров В. Интернет-маркетинг: [краткий курс]. 2-е изд. СПб., 2002. 271 с. 9. Яцишина Л.К., Волкович А.Р. Інноваційні технології в системі маркетингових комунікацій. Ефективна економіка. 2014. 
№ 3. URL: http://www.economy.nayka.com. 10. Смолянюк О.В. Використання соціальних мереж у маркетингових комунікаційних стратегіях підприємств. Економіка та держава. 2016. № 5. C. 105-108. 11. Global B2B e-commerce gross merchandise volume (GMV) from 2013 to 2017 (in billion U.S. dollars). URL: https:/www.statista.com/statistics/705606/global-b2b-ecommerce-gmv/. 12. Global Ecommerce: Statistics and International Growth Trends [Infographic]. URL: https:/www.shopify.com/enterprise/global-ecommercestatistics. 13. Бутенко Н.В. Маркетинг: підручник. Київ: Атіка, 2016. 300 с. 14. Что такое входящий маркетинг (Inbound Marketing)? 2012. URL: https://pgenerator.ru/blog/2012/06/19/chto-takoe-vhodyashij-marketing-inbound-marketing/. 15. Think with Google. URL: https://www.thinkwithgoogle.com/. 16. DeGevter S. How to overcome unique B2B digital marketing challenges. 2018. URL: https://marketingland.com/how-toovercome-unique-b2b-digital-marketing-challenges-234 156. 17. Travis S. 3 insights that will help you serve today's B2B buyer. URL: https://www.thinkwithgoogle. com/advertising-channels/b2b-buyers-online-and-offline/.

18. Бакланова Є. М. Еволюція інструментів і методів маркетингової комунікації в мережі Інтернет. Питання сучасної науки і практики. 2013. № 2 (46). С. 155-159. 19. Богашко О. Л. Теоретичні аспекти дослідження конкурентоспроможності національної економіки в умовах глобалізації. Вісник Бердянського університету менеджменту і бізнесу. Випуск 1 (25). Донецьк, 2014. С. 32 - 37. 20. Гавриков А. Стратегия интернетмаркетинга для В2В. Бесплатный сыр в мышеловке. URL: https://www.marketologi.ru/publikatsii/stati/strate gija-internet-marketinga-dlja-b2b-besplatnyjj-syr-v-mys helovke/. 21. Клічук О. Роль сучасних інформаційних технологій у пошуку оптимальних рішень в економіці. Нова педагогічна думка. 2015. № 1. С. 163-165. 22. Падерін І.Д., Романов О.В., Титовець С.С. Розвиток Інтернет-маркетингу на підприємствах малого та середнього бізнесу. Економічний вісник Донбасу. 2016. №1 (43). C. 120-124.

\section{References}

1. Komarnytskyi I.F. (2006). Ekonomichna teoriia [Economic theory]. Chernivtsi [in Ukrainian].

2. Oklander M.A., Oklander T.O., Yashkina O.I. et al. (2017). Tsyfrovyi marketynh - model marketynhu KhKhI storichchia [Digital Marketing - A 21st Century Marketing Model]. Odesa, Astroprynt [in Ukrainian].

3. Vinarik L.S., Schedrin A.N., Vasilyeva N.F. (2003). Online electronic market: formation, problems. Donetsk, Institute of Industrial Economics of NAS of Ukraine [in Russian].

4. Makarova M.V. (2002). Elektronna komertsiia [Ecommerce]. Kyiv. Academy [in Ukrainian].

5. Strauss J., Frost R. (2001). E-marketing. Upper Saddle River, Prentice-Hall. 519 p.

6. Wilson R. (2003). Internet Marketing Strategy Planning. Trans. from English S.A. Hares. Moscow, Grebennikov Publishing House [in Russian].
7. Uspensky I.V. Internet Marketing. Retrieved from http://www.aup.ru/books/m80/ [in Russian].

8. Kholmogorov V. (2002). Internet marketing [short course]. 2nd ed. SPb [in Russian].

9. Yatsyshyna L.K., Volkovych A.R. (2014). Innovatsiini tekhnolohii v systemi marketynhovykh komunikatsii [Innovative technologies in the system of marketing communications]. Efektyvna ekonomika - Efficient economy, 3. Retrieved from http://www.economy. nayka.com [in Ukrainian].

10. Smolianiuk O.V. (2016). Vykorystannia sotsialnykh merezh u marketynhovykh komunikatsiinykh stratehiiakh pidpryiemstv [Use of social networks in enterprise marketing communication strategies.]. Ekonomika ta derzhava - Economy and the state, 5, pp. 105-108 [in Ukrainian].

11. Global B2B e-commerce gross merchandise volume (GMV) from 2013 to 2017 (in billion U.S. dollars). Retrieved from https://www.statista.com/statistics/7056 06/global-b2b-e-commerce-gmv/.

12. Global Ecommerce: Statistics and International Growth Trends [Infographic]. Retrieved from https: //www.shopify.com/enterprise/global-ecommerce-statistics.

13. Butenko N.V. (2016). Marketynh [Marketing]. Kyiv, Atika [in Ukrainian].

14. Chto takoye vkhodyashchiy marketing (Inbound Marketing)? [What is inbound marketing?]. (2012). Retrieved from https://lpgenerator.ru/blog/2012/06/19/ chto-takoe-vhodyashij-marketing-inbound-marketing/ [in Russian].

15. Think with Google. Retrieved from https: //www.thinkwithgoogle.com/.

16. DeGevter S. How to overcome unique B2B digital marketing challenges. (2018). Retrieved from https://marketingland.com/how-to-overcome-unique-b2b-digitalmarketing-challenges-234156.

17. Travis S. 3 insights that will help you serve today's B2B buyer. Retrieved from https://www.thinkwithgoogle.com/advertising-channels/b2b-buyers-online-andoffline/.

18. Baklanova Ye. M. (2013). Evoliutsiia instrumentiv i metodiv marketynhovoi komunikatsii v merezhi Internet [The evolution of marketing communication tools and methods on the Internet]. Pytannia suchasnoi nauky $i$ praktyky - Questions of modern science and practice, 2 (46), pp. 155-159 [in Ukrainian].

19. Bohashko O. L. (2014). Teoretychni aspekty doslidzhennia konkurentospromozhnosti natsionalnoi ekonomiky v umovakh hlobalizatsii [Theoretical aspects of the study of the competitiveness of the national economy in the context of globalization]. Visnyk Berdianskoho universytetu menedzhmentu i biznesu - Bulletin of Berdyansk University of Management and Business, Issue 1 (25), pp. 32 - 37 [in Ukrainian].

20. Gavrikov A. Internet Marketing Strategy for B2B. Free cheese in a mousetrap. Retrieved from https: //www.marketologi.ru/publikatsii/stati/strategija-internetmarketinga-dlja-b2b-besplatnyjj-syr-v-myshelovke/ [in Russian]. 
21. Klichuk O. (2015). Rol suchasnykh informatsiinykh tekhnolohii $\mathrm{u}$ poshuku optymalnykh rishen $\mathrm{v}$ ekonomitsi [The role of modern information technologies in the search for optimal solutions in the economy.]. Nova pedahohichna dumka - New pedagogical thought, 1, pp. 163-165 [in Ukrainian].

22. Paderin I.D., Romanov O.V., Tytovets Ye.S. (2016). Rozvytok Internet-marketynhu na pidpryiemstvakh maloho ta serednoho biznesu [Development of Internet marketing in small and medium enterprises]. Ekonomichnyi visnyk Donbasu - Economic Herald of the Donbas, 1 (43), pp. 120-124 [in Ukrainian].

Фоміченко І. П., Баркова С. О. Інтернет-маркетинг як інструмент розвитку промислових підприємств в сучасних умовах господарювання

У статті висвітлено значення та основна роль Інтернет-маркетингу у діяльності промислового підприємства. Визначено основні переваги, складові та сегменти Інтернет-маркетингу. Визначено, яким чином особливості діяльності на ринку промислових споживачів впливають на розробку стратегії Інтернет-маркетингу. Виявлено особливі аспекти стратегії Інтернетмаркетингу, які мають бути враховані підприємствами при іiі розробці. Досліджено ключові тенденції у середовищі промислових споживачів, сформовані під впливом розвитку та проникнення Інтернет-технологій у бізнес-середовище. Доведено, що при впровадженні індивідуальних заходів Інтернет-маркетингу спостерігається економія на маркетингових витратах підприємства. Запропоновано складові та інструменти Інтернетмаркетингу промислових підприємств України, які мають бути задіяні у стратегії Інтернет-маркетингу промислових підприємств та шляхи їх використання для підвищення ефективності діяльності підприємств: система автоматизації маркетингу, CRM-система, вебсайт, пошуковий маркетинг, онлайн-маркетплейси, контент-маркетинг.

Ключові слова: Інтернет-маркетинг, інтернет, Інтернет-технології, веб-сервіси, соціальні мережі, стратегія промислового підприємства, ринок електронної комерції.

Fomichenko I., Barkova S. Internet Marketing as a Tool for the Development of Industrial Enterprises in Modern Economic Conditions

The article highlights the values and the main role of Internet marketing in the activities of an industrial enterprise. The main advantages, composition and segments of Internet marketing are defined. It was determined how the features of the activity in the industrial consumer market influence the development of the Internet marketing strategy. Identified specific aspects of the strategy of Internet marketing, which should be taken into account by enterprises in its development. The key trends in the environment of industrial consumers, formed under the influence of the development and penetration of Internet technologies into the business environment, are investigated. It is proved that the introduction of individual activities of Internet marketing, there is a saving on the marketing costs of the enterprise. The composition and tools of Internet marketing of industrial enterprises of Ukraine are proposed, which should be involved in the Internet marketing strategy of industrial enterprises and ways to use them to improve the efficiency of enterprises: a marketing automation system, a CRM system, a website, search marketing, an online marketplace. content marketing.

Keywords: Internet marketing, Internet, Internet technologies, web services, social networks, industrial enterprise strategy, e-commerce market.

Фомиченко И. П., Баркова С. А. Интернет-маркетинг как инструмент развития промышленных предприятий в современных условиях хозяйствования

В статье освящены значения и основная роль Интернет-маркетинга в деятельности промышленного предприятия. Определены основные преимущества, состав и сегменты Интернет-маркетинга. Определено, каким образом особенности деятельности на рынке промышленных потребителей влияют на разработку стратегии Интернет-маркетинга. Выявлены особые аспекты стратегии Интернет-маркетинга, которые должны быть учтены предприятиями при ее разработке. Исследованы ключевые тенденции в среде промышленных потребителей, сформированные под влиянием развития и проникновения Интернет-технологий в бизнес-среду. Доказано, что при внедрении индивидуальных мероприятий Интернет-маркетинга наблюдается экономия на маркетинговых затратах предприятия. Предложено состав и инструменты Интернетмаркетинга промышленных предприятий Украины, которые должны быть задействованы в стратегии Интернет-маркетинга промышленных предприятий та пути их использования для повышения эффективности деятельности предприятий: система автоматизации маркетинга, CRM-система, веб-сайт, поисковый маркетинг, онлайн-маркетплейси, контент-маркетинг.

Ключевые слова: Интернет-маркетинг, Интернет, Интернет-технологии, веб-сервисы, социальные сети, стратегия промышленного предприятия, рынок электронной коммерции.

Received by the editors: 11.11.2019 and final form 19.12.2019 